\title{
Genetic diversity of table grape based on morphoagronomic traits
}

\author{
Patrícia Coelho de Souza Leão ${ }^{1 *}$; Cosme Damião Cruz²; Sérgio Yoshimitsu Motoike ${ }^{3}$ \\ ${ }^{1}$ Embrapa Semi-Árido, Rod. BR 428, km 152, C.P. 23 - 56300-970 - Petrolina, PE, Brasil. \\ ${ }^{2}$ UFV/Centro de Ciências Biológicas e da Saúde - BIOAGRO - 36570-000 - Viçosa, MG - Brasil. \\ ${ }^{3}$ UFV/CCA - Depto. de Fitotecnia, Setor de Fruticultura - 36571-000 - Viçosa, MG - Brasil. \\ *Corresponding autor <patricia@cpatsa.embrapa.br>
}

\begin{abstract}
The conservation and characterization of grape (Vitis spp) genetic resources in germplasm banks have been the basis of its use in breeding programs that result in development of new cultivars. There are at least 10,000 grape cultivars kept in germplasm collection. The genetic diversity in 136 table grape accessions from the state of Bahia, Brazil, was evaluated. Continuous and discrete morphoagronomic traits were assessed. The clustering analysis by the Tocher otimization method resulted in 30 clusters (considering continuous morphoagronomic traits), and 9 clusters (taking into consideration multicategorical traits). There was no agreement between clusters obtained by both, continuous or discrete phenotypic descriptors, independent of the cluster method analysis used. A satisfactory genetic variability among the table grape accessions was observed.
\end{abstract}

Key words: Vitis spp., genetic resources, grape, multivariate analysis

\section{Diversidade genética de acessos de uvas de mesa baseada em caracteres morfoagronômicos}

\begin{abstract}
RESUMO: A conservação e caracterização dos recursos genéticos de videira (Vitis spp.) em bancos de germoplasma tem sido a base para a sua utilização nos programas de melhoramento, que resultam no desenvolvimento de novas cultivares, estimando-se a existência de pelo menos 10.000 cultivares de uva mantidos em coleções de germoplasma. Avaliou-se a diversidade genética presente em 136 acessos de uvas de mesa de uma coleção de germoplasma do estado da Bahia, com base em caraterísticas morfoagronômicas de variação contínua e discreta. A análise de agrupamento pelo método de Tocher resultou na formação de 30 grupos utilizando-se descritores morfo-agronômicos de variação contínua e 9 grupos, com base em caracteres multicategóricos. Não houve concordância entre os grupos obtidos pela análise de descritores fenotípicos contínuos e discretos, independente do método de agrupamento utilizado. Detectou-se a existência de variabilidade genética satisfatória entre os acessos de uvas de mesa da coleção.

Palavras-chave: Vitis spp., recursos genéticos, uva, análise multivariada
\end{abstract}

\section{Introduction}

Methods based on morphoagronomic traits, used to study genetic diversity, have been used since Mendel's time. The ampelography is the field of botany concerned with identification and classification of grape anchored in morphological traits of leaves, apical shoot tips, bunches, and berries (IPGRI, UPOV, OIV 1997; Galet 1998). The ampelography was the predominant method for grape germplasm characterization, since XIX century, until the advent of molecular markers.

The predictive methods based on morphological, agronomical, physiological or genetical traits of genitors, determined prior to the crosses, may help breeders to focus in promising combinations (Cruz et al., 2004). The heterosis, expressed in hybrids, is directly related to the genetic diversity among their genitors ( $\mathrm{Fal}-$ coner, 1989).

The multivariate techniques in the analysis of quantitative and qualitative characteristics have been applied in viticulture with several objectives: to assess the diver- sity of genotypes for disease resistance (Nascimento et al., 2006), management (Intrieri et al., 2001), and morphological and agronomic descriptors (Borges et al., 2008; Micheli et al., 1993; Cravero et al., 1994; Matheou et al., 1995a; Matheou et al., 1995b; Boselli et al., 2000; Coelho et al., 2004).

The diversity of 136 accessions was evaluated using twelve morpho-agronomic traits of continuous variation and six characters of discrete variation during four seasons, with the main objective to characterize and quantify the genetic variability among accessions of table grapes from the Grape Germplasm Collection of EMBRAPA Semiárido.

\section{Material and Methods}

One hundred and thirty six accessions of table grapes (Vitis spp.) from the grapevine germplasm collection of EMBRAPA Semi-Árido, with known geographical origin, species, and genealogies were evaluated (Table 1). The germplasm collection was located in Juazeiro, state 
Table 1 - Table grape accession, classification according to origin, specie, and pedigree evaluated in this study.

\begin{tabular}{|c|c|c|c|c|c|c|c|c|c|}
\hline Accession & $\mathrm{N}$ & Origin & Species & Pedigree & Accession & $\mathrm{N}$ & Origin & Specie & Pedigree \\
\hline A 1105 & 1 & USA & $?$ & & Centennial Seedless & 24 & USA & $V$. vinifera & $\begin{array}{l}\text { Gold } \times \text { Q25-6 (F2 de } \\
\text { Emperor } \times \text { 'Itália') }\end{array}$ \\
\hline A 1118 & 2 & USA & $?$ & & $\begin{array}{l}\text { CG 28467 } \\
\text { (Emperatriz) }\end{array}$ & 25 & Argentina & $V$. vinifera & Emperor $\times$ Sultanina \\
\hline A1581 & 3 & USA & $?$ & & CG 351 (Arizul) & 26 & Argentina & $V$. vinifera & Gibi $\times$ Sultanina \\
\hline A Dona & 4 & Brazil & Hybrid & Soraya $\times$ IAC $544-14$ & CG 38049 & 27 & Argentina & $V$. vinifera & $\begin{array}{l}\text { Riesling } \times(\text { Gibi } \times \\
\text { Sultanina })\end{array}$ \\
\hline Ângelo Pirovano & 5 & Italy & $V$. vinifera & $\begin{array}{c}\text { Chasselas Rose } \times \text { Muscat } \\
\text { Hamburgo }\end{array}$ & CG 39915 & 28 & Argentina & $V$. vinifera & Saint Jeannet $\times$ Sultanina \\
\hline Aurora & 6 & Brazil & Hybrid & IAC $394-16 \times$ Maria & CG 102024 (Dacari) & 29 & Argentina & $V$. vinifera & \\
\hline Baresana & 7 & Italy & $V$. vinifera & & $\begin{array}{l}\text { CG } 102295 \\
\text { (Moscatuel) }\end{array}$ & 30 & Argentina & $V$. vinifera & $\begin{array}{c}\text { 'Moscatel Rosada' no } 2 \times \\
(\text { Cardinal } \times \text { Sultanina })\end{array}$ \\
\hline Beauty Seedless & 8 & USA & $V$. vinifera & $\begin{array}{c}\text { Reine des Vignes } \times \text { Black } \\
\text { Kishmish }\end{array}$ & CG 26858 (Pasiga) & 31 & Argentina & $V$. vinifera & $\begin{array}{c}\text { Alphonsee Lavallee } \times \\
\text { Sultanina }\end{array}$ \\
\hline Beni Fugi & 9 & Japan & Hybrid & $\begin{array}{l}\text { Golden Muscat } \times \\
\text { Kuroshio }\end{array}$ & $\begin{array}{l}\text { CG } 40016 \\
\text { (Damarim) }\end{array}$ & 32 & Argentina & $V$. vinifera & $\begin{array}{l}\text { Moscatel Rosado } \times \\
\text { Sultanina }\end{array}$ \\
\hline Benitaka & 10 & Brazil & $V$. vinifera & Mutation of 'Itália' & CG 90450 & 33 & Argentina & $V$. vinifera & \\
\hline Benitaka & 10 & Brazil & $V$. vinifera & Mutation of 'Itália' & CG 90450 & 33 & Argentina & $V$. vinifera & \\
\hline Blue Lake & 11 & USA & Hybrid & V. smalliana O.P. $\times$ Caco & CG 4113 & 34 & Argentina & $V$. vinifera & Lambrusco $\times$ Carignane \\
\hline Blush Seedless & 12 & USA & $V$. vinifera & $\begin{array}{c}\text { Emperor } \times(\text { Alphonsee } \\
\text { Lavallee } \times \text { Italia }) \times \text { Koen } \\
\text { D. Wein }\end{array}$ & CG 33716 & 35 & Argentina & $V$. vinifera & $\begin{array}{l}\text { Dattier de Beiroth } \times \\
\text { Thompson Seedless }\end{array}$ \\
\hline Branca Salitre & 13 & $?$ & $?$ & & CG 87746 & 36 & Argentina & $V$. vinifera & $\begin{array}{c}\text { Moscato Rosa } \times \text { Beauty } \\
\text { Seedless }\end{array}$ \\
\hline Brazil & 14 & Brazil & $V$. vinifera & Mutation of 'Benitaka' & CG 87908 & 37 & Argentina & $V$. vinifera & \\
\hline Bronx Seedless & 15 & USA & Hybrid & $($ Goff $\times$ Iona $) \times$ Sultanina & CG 26916 (Baviera) & 38 & Argentina & $V$. vinifera & \\
\hline BRS Clara & 16 & Brazil & $V$. vinifera & $\begin{array}{c}\text { CG87746 × Centennial } \\
\text { Seedless }\end{array}$ & Crimson Seedless & 39 & USA & V. vinifera & Emperor $\times$ C33-199 \\
\hline BRS Linda & 17 & Brazil & $V$. vinifera & CG $87746 \times$ Saturn & Christmas Rose & 40 & USA & $V$. vinifera & $\begin{array}{c}(\text { Hunisa } \times \text { Emperor } \times \\
\text { Nocera }) \times(\text { Hunisa } \times \\
\text { Emperor } \times \text { 'Itália' })\end{array}$ \\
\hline BRS Morena & 18 & Brazil & $V$. vinifera & $\begin{array}{l}\text { Marroo Seedless } \times \\
\text { Centennial Seedless }\end{array}$ & Dattier de Beiroth & 41 & Lebanon & $V$. vinifera & \\
\hline Califórnia & 19 & USA & $V$. vinifera & & $\begin{array}{l}\text { Dattier de Saint } \\
\quad \text { Vallier }\end{array}$ & 42 & France & Hybrid & $\begin{array}{l}\text { Panse de Provence } \times \\
\text { Seyve Villard } 12375\end{array}$ \\
\hline Canner & 20 & USA & $V$. vinifera & Hunisa $\times$ Sultanina & Dawn Seedless & 43 & USA & $V$. vinifera & Gold $\times$ Perlette \\
\hline Cardinal & 21 & USA & $V$. vinifera & Flame Tokay $\times$ Ribier & Delight & 44 & USA & $V$. vinifera & $\begin{array}{l}\text { Reine des Vignes } \times \\
\text { Sultanina Branca }\end{array}$ \\
\hline Catalunha & 22 & Brazil & $V$. vinifera & & Dona Maria & 45 & Portugal & $V$. vinifera & $\begin{array}{c}\text { Moscatel de Setubal } \times \\
\text { Rosaki }\end{array}$ \\
\hline Ceilad & 23 & $?$ & $?$ & & Dom Mariano & 46 & $?$ & $?$ & \\
\hline Maria & 85 & Brazil & Hybrid & $\begin{array}{l}\text { (Highland } \times \text { Golden } \\
\text { Queen }) \times \text { Jumbo }\end{array}$ & Perlette & 105 & USA & $V$. vinifera & $\begin{array}{l}\text { Regina del Vigneti } \times \\
\text { Sultanina }\end{array}$ \\
\hline Maroo Seedless & 86 & Australia & Hybrid & $\begin{array}{c}\text { Carolina Blackrose } \times \\
\text { Ruby Sds }\end{array}$ & Perlona & 106 & Italy & $V$. vinifera & $\begin{array}{c}\text { Bicane } \times \text { Muscat } \\
\text { Madresfield }\end{array}$ \\
\hline Mont Serrat & 87 & $?$ & $?$ & & Piratininga & 107 & Brazil & Hybrid & $\begin{array}{l}\text { Mutation of 'Eugênio' } \\
((\text { Seibel } 7053 \times \text { Muscat } \\
\text { Hamburgo }) \times \text { Soraya) }\end{array}$ \\
\hline $\begin{array}{l}\text { Moscato de } \\
\text { Alexandria }\end{array}$ & 88 & Egypt & $V$. vinifera & & Seleção 01 & 108 & $?$ & $?$ & \\
\hline Moscatel Branca & 89 & $\begin{array}{l}\text { Italy-Por- } \\
\text { tugal }\end{array}$ & $V$. vinifera & & Seleção 02 & 109 & $?$ & $?$ & \\
\hline $\begin{array}{l}\text { Muscat de } \\
\text { Hamburgo }\end{array}$ & 90 & German & $V$. vinifera & $\begin{array}{c}\text { Schiava Grossa } \times \text { Muscat } \\
\text { de Alexandria }\end{array}$ & Seleção 04 & 110 & $?$ & $?$ & \\
\hline Moscato Grego & 91 & France & $V$. vinifera & & Portuguesa Blanes & 111 & ? & ? & \\
\hline $\begin{array}{l}\text { Moscatel } \\
\text { Nazareno }\end{array}$ & 92 & Portugal & $V$. vinifera & $\begin{array}{l}\text { Muscat de Hamburgo } \times \\
\text { Joao Santarém }\end{array}$ & Princess & 112 & USA & Hybrid & $\begin{array}{c}\text { Crimson Seedless } \times \text { Fresno } \\
\text { B40-208 }\end{array}$ \\
\hline Moscatel Rosada & 93 & Portugal & $V$. vinifera & $\begin{array}{c}\text { Diagalves } \times \text { Moscatel de } \\
\text { Málaga }\end{array}$ & Queen & 113 & USA & $V$. vinifera & $\begin{array}{c}\text { 'Muscat de Hamburgo' } \times \\
\text { Sultanina }\end{array}$ \\
\hline Muscat Caillaba & 94 & France & $V$. vinifera & & Red Globe & 114 & USA & $V$. vinifera & $\begin{array}{c}(\text { Hunisa } \times \text { Emperor }) \times \\
(\text { Hunisa } \times \text { Emperor } \times \\
\text { Nocera })\end{array}$ \\
\hline
\end{tabular}

Contine... 
Table 1 - Continuation.

\begin{tabular}{|c|c|c|c|c|c|c|c|c|c|}
\hline Muscat Noir & 95 & France & $V$. vinifera & & Regina dei Vigneti & 115 & Hungary & $V$. vinifera & $\begin{array}{c}\text { Erzseber Kiralyne Emleke } \\
\times \text { Perle von Csaba }\end{array}$ \\
\hline $\begin{array}{l}\text { Muscat de Saint } \\
\text { Vallier }\end{array}$ & 96 & France & Hybrid & $\begin{array}{l}\text { Seyve Villard } 12-129 \times \\
\text { Panse }\end{array}$ & Regina Roma & 116 & $?$ & $?$ & \\
\hline Neo Muscat & 97 & Japan & $V$. vinifera & $\begin{array}{c}\text { Muscat de Alexandria } \times \\
\text { Koshu Sanjaku }\end{array}$ & Reliance & 117 & USA & Hybrid & Ontario $\times$ Suffolk Red \\
\hline Neptune & 98 & USA & Hybrid & & Rodi & 118 & Italy & $V$. vinifera & Zibibbo $\times$ Sultanina \\
\hline Niagara Rosada & 99 & Brazil & V. labrusca & Mutation of 'Niágara' & Roni Redi & 119 & $?$ & $?$ & \\
\hline Orange Muscat & 100 & France & $V$. vinifera & & Rosaki Rosada & 120 & $?$ & $V$. vinifera & \\
\hline Panse Precoce & 101 & Italy & $V$. vinifera & & Ruby Seedless & 121 & USA & $V$. vinifera & $\begin{array}{c}\text { Emperor } \times \text { Sultana } \\
\text { Moscata }\end{array}$ \\
\hline Patrícia & 102 & Brazil & Hybrid & $\begin{array}{c}\text { Soraya } \times((\text { Muscat } \\
\text { Hamburgo } \times \text { V. cinérea }) \\
\times(\text { Red Niagara } \times \\
\text { Jumbo }))\end{array}$ & Saint Jeannet & 122 & France & $V$. vinifera & \\
\hline Paulistinha & 103 & Brazil & Hybrid & $\begin{array}{c}\text { 'Niagara Branca' } \times \\
\text { Sultanina }\end{array}$ & Saturn & 123 & USA & Hybrid & $\begin{array}{c}\text { Dunstan } 210 \times \text { New York } \\
45791\end{array}$ \\
\hline Perla de Gralia & 104 & $?$ & $?$ & & Seyve Villard 12327 & 124 & France & Hybrid & Seibel $6468 \times$ Seibel 6905 \\
\hline $\begin{array}{l}\text { Seyve Villard } \\
12375\end{array}$ & 125 & France & Hybrid & Seibel $6468 \times$ Seibel 6905 & Superior Seedless & 131 & USA & $V$. vinifera & Cardinal $\times$ ? \\
\hline $\begin{array}{l}\text { Seyve Villard } \\
20365\end{array}$ & 126 & France & Hybrid & $\begin{array}{l}\text { Panse de Provence } \times \\
\text { Seyve Villard } 12375\end{array}$ & Sultanina Branca & 132 & Turkey & $V$. vinifera & $\begin{array}{c}\text { Clone de Thompson } \\
\text { Seedless }\end{array}$ \\
\hline Soraya & 127 & Brazil & Hybrid & $\begin{array}{c}\text { (Highland } \times \text { Golden } \\
\text { Queen }) \times \text { Pirovano } 215\end{array}$ & Sultana Moscata & 133 & Italy & $V$. vinifera & Zibibbo $\times$ Sultanina \\
\hline $\begin{array}{l}\text { Sovrana } \\
\text { Pirovano }\end{array}$ & 128 & Italy & $V$. vinifera & $\begin{array}{c}\text { Frakenthal } \times \text { Delizia de } \\
\text { Vaprio }\end{array}$ & Tardia de Caxias & 134 & Brazil & Hybrid & $\begin{array}{c}\text { Niagara Branca } \times \text { Catawba } \\
\text { Rosa }\end{array}$ \\
\hline Stover & 129 & USA & Hybrid & Mantey $\times$ Roucaneuf & Thompson Seedless & 135 & Turkey & $V$. vinifera & \\
\hline Suffolk Red & 130 & USA & Hybrid & $\begin{array}{c}\text { Fredonia } \times \text { Kishmish } \\
\text { Chernyi }\end{array}$ & Vênus & 136 & USA & Hybrid & Alden $\times$ New York 46000 \\
\hline
\end{tabular}

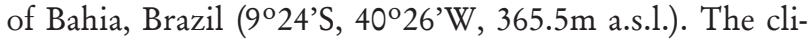
mate is classified according to Koeppen, as Bswh, which corresponds to the semi-arid hot, with average annual precipitation of $505 \mathrm{~mm}$, annual average relative humidity of $60.7 \%$, annual average temperature, maximum, and minimum, respectively $26.7^{\circ} \mathrm{C}, 32.0^{\circ} \mathrm{C}$, and $20.8^{\circ} \mathrm{C}$ (www.cpatsa.embrapa.br/servicos/dadosmet/cemanual.html).

Mean values were obtained from four plants in four seasons based on 12 morphoagronomic characteristics of continuous variation. The traits were chosen from the list of descriptors of the International Plant Genetic Resources Institute (1997), for its importance in the yield and fruit quality: i) duration of the phenological cycle (CD), measured from the date of pruning to harvest (days), ii) production of bunches per plant (PR) - weight of all bunches per plant $(\mathrm{kg})$, iii) number of bunches per plant (NB); iv) mean bunches weight (BW) - total weight of all bunches divided by the total number of bunches per plant (g), v) bunches length (BL), measured between the top and bottom of the rachis ( $\mathrm{cm})$, vi) width of the bunches (WB), measured between both extremity side of the rachis (cm), vii) weight of berries (WBe) - mean weight of ten berries per bunch $(\mathrm{g})$, viii) length of berry $(\mathrm{LBe})$ - mean length of ten berries per bunch (mm), ix) diameter of berry $(\mathrm{DBe})$ - mean diameter of ten berries per bunch (mm), x) total soluble solids (TSS), determined from a sample of ten berries per bunch in ${ }^{\circ}$ Brix; xi) titratable acidity (TTA), determined from a sample of ten berries per bunch in percentage of tartaric acid / $100 \mathrm{~mL}$ of juice; and xii) the total soluble solids (TSS)/ total titratable acidity (TTA). Six discrete characteris- tics were also evaluated, coded as follows: i) consistency of the pulp: crisp (1), fleshy (2), muscilaginous (3), or juicy (4); ii) Presence of seeds: present (1) or absent (2); iii) Taste: neutral (1), special (2) muscat (3) or foxy (4); iv) Format of bunches: cylindrical (1), cylindrical winged (2) or cone (3); v) Format berries: ovoid (1), globose (2) or elliptical (3); vi) Color: Black (1), red (2), green (3) or green-yellow (4).

Statistical analysis was performed using the software Genes (http://www.ufv.br/dbg/genes/Genes) EUA.htm (Cruz, 2008). To carry out the multivariate analysis, the genetic distances between all pairs of accessions were obtained, using Mean Euclidean distance for continuous variables, and the index of dissimilarity for multicategorical variables. The index of dissimilarity between each pair of accessions was set according to the: agreement (A) and disagreement (D) of categories or statistical classes for the traits studied. Cluster analysis was performed by Tocher's optimization procedure.

The diversity among accessions based on discrete variables was visualized through graphical projection of distances in three dimensional spaces. The efficiency of the projection was estimated by the following statistics: i) Degree of distortion, ii) Coefficient of correlation between the original distances and those represented in the dispersion graph, and iii) Stress coefficient of Kruskal (1964).

Diversity was also analyzed using the method of multivariate analysis of principal components (Cruz et al., 2004) for continuous variable. The relative importance of characters, used in the discrimination of clusters, was assessed at the discretion of the weight variables in eigen- 
vectors. The eigenvectors and eigenvalues were obtained from the correlation matrix of standardized data of original values. The characters with higher weights in the last five eigenvectors, up to a value less than or equal to 0.70 , have lower contribution in the discrimination of groups and should be discarded (Cruz et al., 2004). Then, the dissimilarities between accessions were viewed by means of dispersion imaging in three dimensional space.

\section{Results and Discussion}

Thirty clusters were obtained by Tocher's optimization procedure for twelve continuous variables in 136 accessions of table grapes (Table 2). Cluster 1 included $30.14 \%$ of the accessions from the collection. In general, it was not possible to identify a trend in the formation of clusters such as genealogy or geographical origin. Clusters 1 and 2 grouped cultivars of different geographical origins, different species such as Vitis vinifera, Vitis labrusca, Vitis interspecific hybrids, and seeded and seedless grape cultivars. These results agree with those obtained in guarana (Paullinia cupana Kunth.) (Nascimento Filho et al., 2001) and cowpea (Vigna unguiculata L.) (Oliveira et al., 2003), where there was no occurrence of correlation between geographical and genetical diversity. Martinelli et al. (2002) also did not obtain a separation of the accessions of okra (Abelmoschus esculentus Moench), according to their botanical specie, when using multivariate analysis of quantitative traits. According to Martinelli et al. (2002), characteristics controlled by many genes and affected by environmental factors may be a suitable explanation.

Table 2 - Grouping according to Tocher's optimization procedure, considering twelve characters of continuous variation evaluated in 136 accessions of table grapes.

\begin{tabular}{|c|c|}
\hline Cluster & Accessions \\
\hline 1 & $\begin{array}{lllllllllllllllllllllllll}49 & 76 & 77 & 75 & 60 & 89 & 63 & 100 & 124 & 96 & 101 & 2 & 83 & 8 & 104 & 91 & 59 & 125 & 62 & 118 & 37 & 80 & 82 & 39 & 58 \\
123 & 12 & 135 & 36 & 103 & 117 & 136 & 15 & 43 & 20 & 24 & 32 & 22 & 133 & 105 & 132 & & & & & & & & \end{array}$ \\
\hline 2 & $\begin{array}{llllllllllllllllllllllll}90 & 95 & 92 & 94 & 86 & 7 & 93 & 88 & 61 & 13 & 57 & 67 & 106 & 9 & 127 & 116 & 84 & 78 & 111 & 97 & 122 & 71 & 107 & \end{array}$ \\
\hline 3 & $\begin{array}{llllllll}10 & 14 & 113 & 72 & 114 & 45 & 33\end{array}$ \\
\hline 4 & $6 \quad 66 \quad 79 \quad 68$ \\
\hline 5 & $\begin{array}{lllllll}41 & 46 & 40 & 38 & 53 & 52 & 42\end{array}$ \\
\hline 6 & $\begin{array}{llllllllll}5 & 19 & 126 & 25 & 112 & 98 & 1 & 51 & 26 & 28\end{array}$ \\
\hline 7 & $23 \quad 35 \quad 128 \quad 34$ \\
\hline 8 & $108 \quad 109 \quad 110$ \\
\hline 9 & $\begin{array}{lllll}16 & 65 & 18 & 99\end{array}$ \\
\hline 10 & $21 \quad 115 \quad 131 \quad 29 \quad 3$ \\
\hline 11 & $44 \quad 130$ \\
\hline 12 & $\begin{array}{lll}64 & 81 & 27\end{array}$ \\
\hline 13 & $4 \quad 102$ \\
\hline 14 & $55 \quad 56$ \\
\hline 15 & $11 \quad 129$ \\
\hline 16 & $69 \quad 85$ \\
\hline 17 & 5073 \\
\hline 18 & 87 \\
\hline 19 & 121 \\
\hline 20 & 54 \\
\hline 21 & 120 \\
\hline 22 & 30 \\
\hline 23 & 74 \\
\hline 24 & 47 \\
\hline 25 & 119 \\
\hline 26 & 70 \\
\hline 27 & 31 \\
\hline 28 & 17 \\
\hline 29 & 48 \\
\hline 30 & 134 \\
\hline
\end{tabular}


Cluster 1 had a predominance of seedless grape cultivars, which represented $63.4 \%$ of this cluster; 'Thompson Seedless' and its synonyms 'Catalunha' and 'Sultanina Branca' were included in this group. Most cultivars of the muscat type were included in cluster 2. Cluster 3 was composed of clones of 'Itália' of red berries such as 'Benitaka' and 'Brasil', and 'Itália Muscat', which has soluble solids content and muscat flavor greater the cultivar 'Itália'. Predominant cultivars in this cluster are distinguished by the size of their berries. Besides those already mentioned, also belong to this group: 'CG 90450', 'Dona Maria', 'Queen', and 'Red Globe'. Clones and synonyms such as 'Dattier de Saint Vallier' and 'Seyve Villard 20365', 'Emperatriz' and 'CG 28467' were separated into distinct groups, showing that the technique of grouping morphoagronomic traits using continuous cluster was not efficient to group identical genotypes. The cluster 17, which has included the cultivars 'Itália clone 1' and 'Estevão Marinho', was highlighted by the production and bunches sizes.

Considering all the possible combinations for each accession, the majority presented maximum distances for two cultivars: 'Tardia de Caxias' (accession 134) and 'Itália clone 1' (accession 73), indicating that these cultivars were the more divergent of this table grape set. The maximum distance observed between both was $\mathrm{d}$ $=3.55$, whereas, the cultivars Early Muscat and July Muscat showed the smallest distance $(\mathrm{d}=0.21)$ between all pairs of accessions analyzed.

The mean value of a segregating population depends on the frequency of favorable alleles and the frequency of loci in heterozygosity. When the parents used are adapted, the frequency of favorable alleles is high. Vine has been selected and vegetatively propagated over thousands of years since the beginning of the process of domestication and cultivation, which contributed to the accumulation of favorable alleles. Being a species highly heterozygous, it is hoped, therefore, to obtain the maximum heterotic effect in segregating generations from the crossing of divergent parents. Considering the multivariate statistics, it is expected to find high similarity between the genotypes belonging to the same cluster. Thus, crossing within the same cluster should be avoided. According to Nascimento Filho et al. (2001), the crossing of more productive guarana clones, in the different clusters, allowed to obtain populations highly segregating.

There was genetic variability among accessions in this collection, revealed by the large number of clusters formed and satisfactory distribution of the accessions within these groups. This enables the identification of parents that may form segregating populations with broad genetic base. For the development of new table seedless grape cultivars, one of the strategies suggested is the use of 'Thompson Seedless' (cluster 1) as male parent, with cultivars that were more divergent, higher productive, and possess large berries such as 'Italy clone 1' $(\mathrm{d}=2.60)$ and 'Estevão Marinho' $(\mathrm{d}=2.50)$, both in clus- ter 17. Other recommended crosses would be: 'Thompson Seedless' with 'Itália melhorada' $(\mathrm{d}=2.03)$ (cluster 23), 'Red Globe' $(\mathrm{d}=2.22)$ or 'Dona Maria' $(\mathrm{d}=2.08)$ (cluster 3).

Using multivariate analysis by principal components, most of the variability was retained in the first four principal components that explained $82.78 \%$ of the variance and were used to plot the accessions in the three-dimensional space (Figure 1). The principal component 1, representing $44.16 \%$ of total variance, and the variables with higher weight in this component were bunches weigh, berry weight, and berry diameter (Table 3). Component 2 explained $16.67 \%$ of the total variance, and it was associated with the following characteristics: TSS/TTA and titratable acidity (TTA). Component 3 explained $14.77 \%$ of the variance of the original data and was represented mainly by the variable number of bunches per plant, total soluble solids (TSS) and yield per plant. Component 4 , represented $7.18 \%$ of total variance, and the variable with higher weight was the total soluble solids (TSS).

The characters with higher weights in the last five eigenvectors, up to a value less than or equal to 0.70 , have lower contribution in the discrimination of groups and should be discarded (Cruz et al. 2004). They were, in decreasing order of importance: bunch weight (BW), weight of berries (WBe), TSS/TTA, width of bunch (WB), and length of berry (LBe).

The score graph of the four first principal components showed that there was consistency with the groups formed by Tocher's optimization procedure. Borges et al. (2008) also found correlation between groups obtained by Tocher's optimization procedure and principal components when studying a set of 58 accessions of this collection. This can be seen in Figures $1 \mathrm{~A}$ and $1 \mathrm{~B}$, considering the groups with the highest number of accessions, clusters 1 and 4 positioned to the right side of the $\mathrm{X}$ axis, while clusters 2 and 3 were located on the left, and clusters 5 and 6 in the lower portion. The cultivars 'Tardia de Caxias' (accession 134) and 'Itália clone 1' (accession 73), which showed maximum distance, were positioned at opposite ends in three-dimensional space.

Significant correlations $(p<0.05$ and $p<0.01)$ were observed among traits studied, but in general, they were of low magnitude (Table 4). In particular, the correlations $(p<0.01)$ between bunch weight and characteristics of size of bunches and berries were positive and significant: bunch length $(r=0.76)$, width of bunch $(r=$ $0.86)$, weigh of berry $(r=0.76)$, length of berry $(r=0.61)$, and diameter of berry $(r=0.76)$. Other high positive correlations were obtained between length and width of bunches $(r=0.78)$, berry weight and berry length $(r=$ $0.85)$, berry weight and berry diameter $(r=0.92)$, and length and diameter of berries $(r=0.81)$, whereas a significant negative correlation between titratable acidity and TSS/TTA $(r=-0.83)$ was observed. Considering the results obtained by analysis of principal components and correlations, the variable berry weight could in future work be refused in the evaluation accessions of 
Table 3 - Estimates of eigenvalues $(\lambda)$ and eigenvectors associated with the principal components in 136 accessions of table grapes and twelve morphological and agronomic of continuous variation. Bold values highlight the characteristic of greater weight in their eigenvector.

\begin{tabular}{lcccccccccccc}
\hline Trait & CP 1 & CP 2 & CP 3 & CP 4 & CP 5 & CP 6 & CP 7 & CP 8 & CP 9 & CP 10 & CP 11 & CP 12 \\
\hline CD & 0.2515 & -0.1477 & 0.2658 & -0.421 & 0.0973 & 0.7984 & -0.022 & 0.0334 & 0.018 & 0.0719 & 0.0972 & 0.0644 \\
PR & 0.2563 & 0.3813 & 0.3874 & -0.0758 & -0.0627 & -0.2582 & 0.1529 & -0.1286 & 0.4327 & 0.0558 & 0.3082 & 0.4871 \\
NB & -0.0108 & 0.3343 & 0.5801 & -0.293 & -0.226 & -0.1949 & 0.2577 & 0.2214 & -0.2835 & -0.0724 & -0.2192 & -0.3572 \\
BW & 0.3999 & 0.141 & -0.0072 & 0.1365 & 0.1242 & 0.0502 & -0.3265 & -0.1463 & 0.4547 & -0.0843 & -0.3521 & -0.5637 \\
BL & 0.3233 & 0.2076 & -0.0461 & 0.2754 & 0.4335 & 0.0559 & -0.7424 & -0.1519 & -0.0211 & -0.062 & -0.0012 & 0.0535 \\
WB & 0.3525 & 0.2129 & 0.0039 & 0.2569 & 0.329 & -0.0115 & -0.4173 & 0.4571 & -0.4995 & 0.0934 & 0.0705 & 0.099 \\
WBe & 0.3853 & -0.0597 & -0.1435 & -0.0568 & -0.3783 & 0.0033 & -0.0233 & -0.1811 & -0.2253 & -0.2826 & -0.5689 & 0.4397 \\
LBe & 0.3407 & -0.1866 & -0.2233 & 0.0328 & -0.3931 & -0.06 & 0.2744 & 0.649 & 0.3205 & 0.169 & 0.1018 & -0.0439 \\
DBe & 0.383 & 0.0016 & -0.1555 & -0.032 & -0.3646 & -0.0626 & -0.0113 & -0.4365 & -0.3442 & 0.1123 & 0.5181 & -0.3179 \\
TSS & -0.0923 & -0.1345 & 0.4423 & 0.7187 & -0.3244 & 0.2636 & 0.0128 & -0.0944 & -0.0222 & 0.263 & -0.0818 & 0.0323 \\
TTA & -0.2049 & 0.5025 & -0.1979 & 0.1898 & -0.2716 & 0.3766 & -0.0299 & 0.1456 & 0.0536 & -0.5821 & 0.2238 & -0.0275 \\
TSS/TTA & 0.1432 & -0.5511 & 0.3334 & 0.1133 & 0.1202 & -0.1826 & -0.0347 & 0.0728 & 0.0072 & -0.6601 & 0.2436 & -0.0493 \\
\hline$\lambda$ & 5.30 & 2.00 & 1.77 & 0.86 & 0.78 & 0.52 & 0.25 & 0.16 & 0.12 & 0.09 & 0.08 & 0.06 \\
\hline$\lambda$ (\%) accumulated & 44.16 & 60.84 & 75.60 & 82.78 & 89.27 & 93.64 & 95.73 & 97.09 & 98.10 & 98.88 & 99.53 & 100 \\
\hline
\end{tabular}

$\mathrm{CD}=$ duration of the phenological cycle (days), $\mathrm{PR}=$ production of bunches per plant ( $\mathrm{kg}$ ), $\mathrm{NB}=$ number of bunches per plant, $\mathrm{BL}$ $=$ bunches length, $\mathrm{WB}=$ bunches weight, $\mathrm{WBe}=$ weight of berries, $\mathrm{LBe}=$ length of berry, $\mathrm{DBe}=$ diameter of berry, $\mathrm{TSS}=$ total soluble solids, TTA $=$ total titratable acidity, TSS/TTA $=$ ratio total soluble solids (TSS) / total titratable acidity (TTA).

Table 4 - Pearson's correlation coefficients obtained among twelve traits, of continuous variation, in 136 accessions of table grapes from the vine germplasm collection of EMBRAPA Semi-Árido.

\begin{tabular}{|c|c|c|c|c|c|c|c|c|c|c|c|}
\hline Trait & DC & PR & NB & BW & BL & WB & WBe & $\mathrm{LBe}$ & $\mathrm{DBe}$ & TSS & TTA \\
\hline $\mathrm{CD}$ & $0.24 \% *$ & & & & & & & & & & \\
\hline PR & $0.28 \% *$ & $0.1^{\mathrm{ns}}$ & & & & & & & & & \\
\hline NB & $0.46 \% *$ & $0.59 * *$ & $0.23^{\mathrm{ns}}$ & & & & & & & & \\
\hline BW & $0.30 \% *$ & $0.43 * *$ & $0.07^{\mathrm{ns}}$ & $0.76 \% *$ & & & & & & & \\
\hline BL & $0.34 \% *$ & $0.57 * *$ & $0.12^{\mathrm{ns}}$ & $0.86^{* * *}$ & $0.78^{* * *}$ & & & & & & \\
\hline WB & $0.45 \% *$ & $0.31 * *$ & $0.23 \% *$ & $0.76 \% *$ & $0.51 \% *$ & $0.58 \% *$ & & & & & \\
\hline WBe & $0.34 * \%$ & $0.14^{\mathrm{ns}}$ & $0.17 *$ & $0.61 \% *$ & $0.43 * *$ & $0.46 * *$ & $0.85 \%$ & & & & \\
\hline $\mathrm{LBe}$ & $0.39 \% *$ & $0.36 \%$ & $0.19 *$ & $0.76 \% *$ & $0.54 * \%$ & $0.61 \% *$ & $0.92 \% *$ & $0.81 \% *$ & & & \\
\hline $\mathrm{DBe}$ & $-0.05^{\mathrm{ns}}$ & $-0.01^{\mathrm{ns}}$ & $0.05^{\text {ns }}$ & $-0.18 *$ & $-0.17 *$ & $-0.16^{*}$ & $-0.22 * *$ & $-0.19 *$ & $-0.24 * \%$ & & \\
\hline TSS & $-0.44 \% *$ & $-0.09^{\text {ns }}$ & $-0.1^{\mathrm{ns}}$ & $-0.28^{\% * \%}$ & $-0.18 *$ & $-0.19 *$ & $-0.36^{* * \%}$ & $-0.39 * * \%$ & $-0.31 * \%$ & $0.03^{\text {ns }}$ & \\
\hline TTA & $0.40 \% *$ & $0.01^{\text {ns }}$ & $0.07^{\text {ns }}$ & $0.16^{\mathrm{ns}}$ & $-0.05^{\text {ns }}$ & $0.09^{\text {ns }}$ & $0.24 * *$ & $0.30 \% *$ & $0.16^{\mathrm{ns}}$ & $0.33 \%$ & $-0.83 * *$ \\
\hline
\end{tabular}

** and * significant at 1 and $5 \%$ of probability, respectively, by the $t$ test. $C D=$ duration of the phenological cycle (days), PR = production of bunches per plant (kg), NB = number of bunches per plant, $\mathrm{BL}=$ bunches length, $\mathrm{WB}=$ bunches weight, $\mathrm{WBe}=$ weight of berries, $\mathrm{LBe}=$ length of berry, $\mathrm{DBe}=$ diameter of berry, TSS $=$ total soluble solids, TTA $=$ total titratable acidity.

table grapes using morpho-agronomic traits of continuous variation.

Cluster analysis by the Tocher's optimization procedure resulted in the formation of 9 groups, concentrating $35.3 \%$ of accessions in group 1 (Table 5). Cluster 3 consisted only of accessions with muscilaginous and juicy pulp consistency and the vast majority of muscat type cultivars. The American cultivars were also included in this cluster. Cluster 4 was formed exclusively by seedless grape cultivars. The red clones of the cultivar Itália, 'Benitaka' and 'Brasil' were included in cluster 1 together with 'Itália' and clone 'Itália 1', both of white berries. However, the clones 'Itália melhorada' and 'Itália Muscat', which are differentiated by the more accentuated moscatel taste, were placed in cluster 7. It was not possible to group the accessions that are synonyms, i.e., they represent the same phenotype when using discrete variables.

The projection of the distances (Figure 2) demonstrated the formation of two distinct groups in the threedimensional space, considering as a classificatory variable: presence/absence of seeds in the berries. The correlation between original and estimated distances was 0.71 , while the degree of distortion was $13.21 \%$, and the 
Table 5 - Grouping according to Tocher's optimization procedure, based on six multicategorical variables evaluated in 136 accessions of table grapes.

\begin{tabular}{|c|c|}
\hline Cluster & Accessions \\
\hline 1 & $\begin{array}{lllllllllllllllllllllllllllll}1 & 38 & 42 & 116 & 47 & 57 & 84 & 127 & 87 & 10 & 14 & 40 & 52 & 102 & 41 & 53 & 25 & 61 & 26 & 107 & 45 & 115 & 46 & 78 & 113 & 114 & 5 & 71 & 96 \\
82 & 100 & 3 & 2 & 13 & 101 & 29 & 21 & 33 & 105 & 60 & 134 & 73 & 27 & 83 & 104 & 76 & 120 & 50 & & & & & & & & & \end{array}$ \\
\hline 2 & $\begin{array}{llllllllllllllll}8 & 86 & 44 & 108 & 125 & 19 & 109 & 110 & 126 & 111 & 23 & 12 & 124 & 128 & 55\end{array}$ \\
\hline 3 & 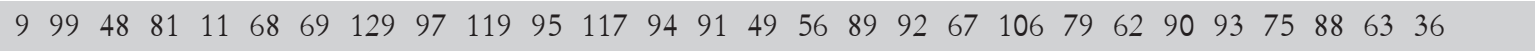 \\
\hline 4 & $\begin{array}{lllllllllllllllllllllllllll}16 & 43 & 112 & 18 & 54 & 39 & 22 & 24 & 135 & 28 & 17 & 70 & 98 & 20 & 35 & 131 & 58 & 118 & 121 & 4 & 51 & 123 & 59 & 132 & 77 & 65 & 133\end{array}$ \\
\hline 5 & $\begin{array}{llllllllll}6 & 122 & 7 & 37 & 32 & 80 & 31 & 85 & 130 & 30\end{array}$ \\
\hline 6 & 3410315 \\
\hline 7 & $7274 \quad 66$ \\
\hline 8 & 64 \\
\hline 9 & 136 \\
\hline
\end{tabular}
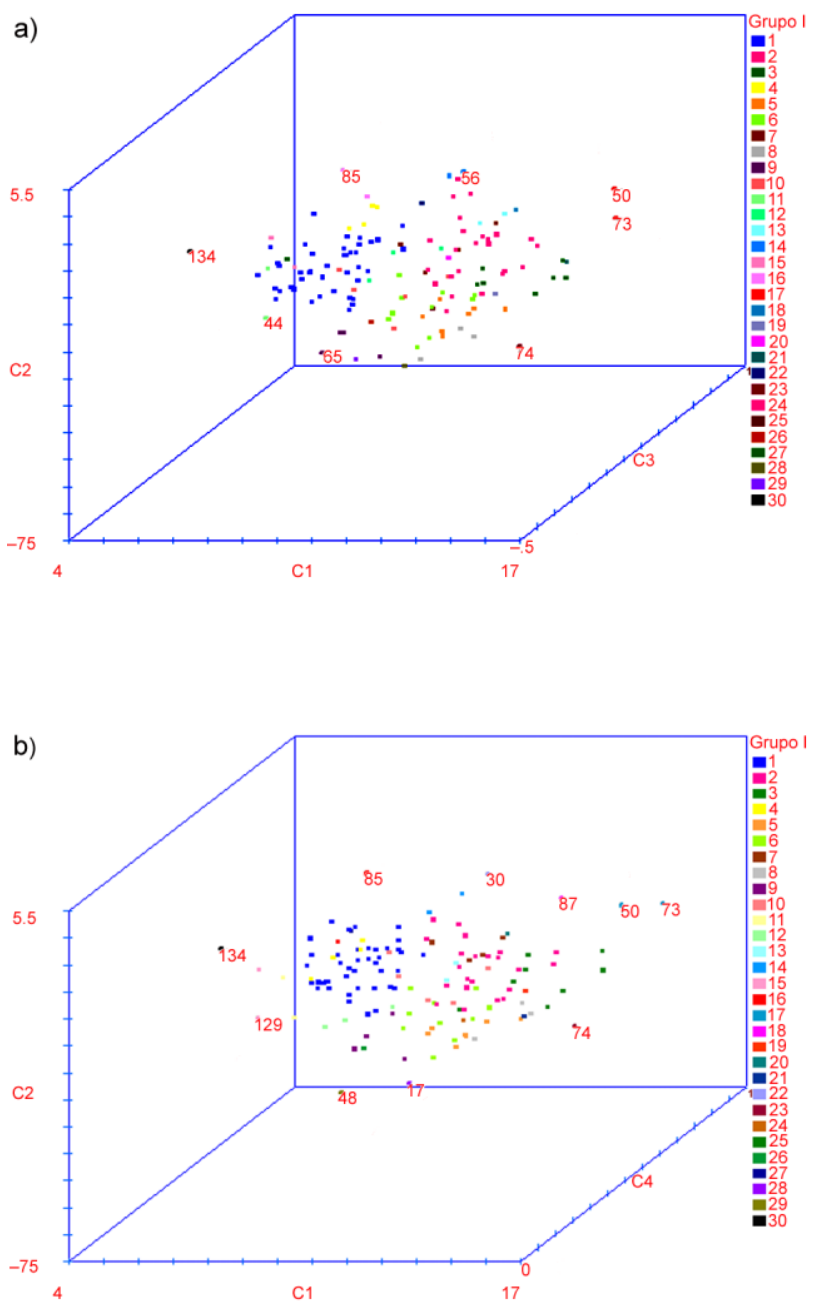

Figure 1 - Graphical dispersion of 136 accessions of table grapes in relation to principal components 1,2 , and 3 (a) and 1,2 , and 4 (b) established by the linear combination of 12 morphoagronomic characters of continuous variation. The colors differentiate the groups according to the Tocher's cluster analysis.

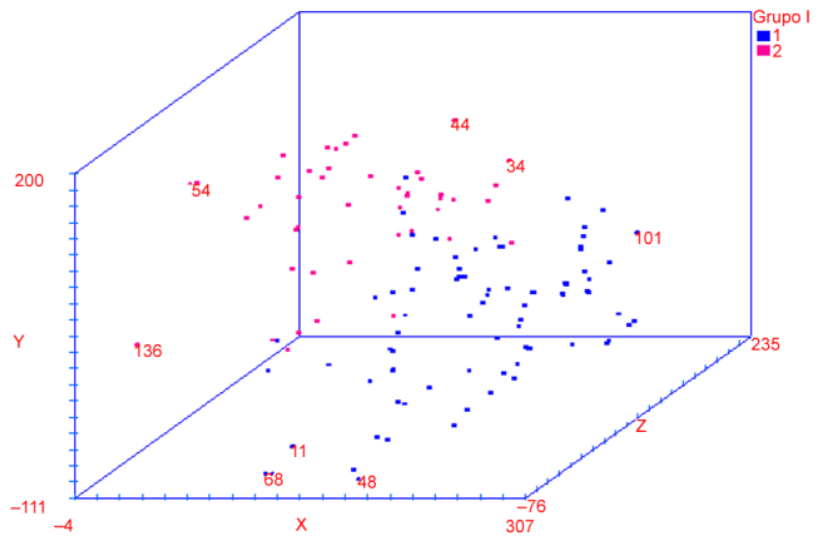

Figure 2 - Graphical projection of the distances of 136 accessions of table grapes, estimated from six morphoagronomic discrete traits using as a classificatory variable: presence (group 1) or absence of seeds (group 2).

stress coefficient was 27.88. According to Cruz et al. (2004), the dispersion process of dissimilarity measures in the plan can be considered satisfactory, when the coefficients that express the degree of distortion and stress, are less than $20 \%$.

\section{Conclusions}

The multivariate techniques to study genetic diversity applied to continuously variable characters are consistent with each other. However, there is no correlation between the formation of the clusters using continuous and multicategorical variables. The characteristic 'weight of berry' can be refuse in future work on morpho-agronomic evaluation of accessions of table grapes. Cluster analysis based on morpho-agronomic characters resulted in the separation of accessions according to common characteristics such as weight and berry production (continuous variables), consistency of the pulp and the presence of seeds (multicategorical variables), but is not efficient in group identical or synonyms genotypes. 


\section{References}

Borges, R.M.E.; Gonçalves N.P.S.; Gomes A.P.O.; Alves E.O.S. 2008. Phenotypic divergence among table grapes accesses in the Brazilian Semi-Arid. Pesquisa Agropecuária Brasileira 43: 10251030. (in Portuguese, with abstract in English).

Boselli, M.; Corso, C.; Monaco, A. 2000. Amplographic characterization of white grape varieties in Campania (Southern Italy) by multivariate analysis. Acta Horticulturae 528: 75-81.

Coelho, I.; Cunha, J.; Cunha, J.P.; Carneiro, L.C.; Castro, R.; Eira Dias, J.E. 2004. Ampelometric comparison of wild vine Vitis vinifera L. populations and old grapevine cultivars of the south of Portugal. Ciência e Técnica Vitivinícola, Dois Portos 19: 112. (in Portuguese, with abstract in English).

Cravero, M.C.; Guidoni, S.; Schneider, A.; Stefano, R. 1994 Morphological and biochemical characterisation of coloured berry-muscat grapevine cultivars. Vitis 33: 75-80.

Cruz, C.D. 2008. Genes Software: Genetic Diversity. Viçosa Press, Viçosa, MG, Brazil. (in Portuguese).

Cruz, C.D.; Regazzi, A.J.; Carneiro, P.C.S. 2004. Biometric Models Applied to Breeding. 3ed. Viçosa Press, Viçosa, MG, Brazil. (in Portuguese).

Falconer, D.S. 1989. Introduction to Quantitative Genetics. 3ed. Longman, New York, NY, USA.

Galet, P. 1998. Grape Varieties and Rootstocks Varieties. Oenoplurimédia, Paris, France, 315 p.

Intrieri, C.; Silvestroni, O.; Filipetti, I.; Bucchetti, B. 2001. Assessment of a cv. Sangiovese clone's morphological variability in differing environmental and management conditions. Advances in Horticultural Science 15: 79-84.

International Plant Genetic Resources Institute. 1997. Descriptors for Grapevine (Vitis spp). IPGRI, Rome, Italy, 62 p.
Kruskal, J.B. 1964. Multidimensional scaling by optimizing goodness of fit to a non-metric hypothesis. Psychometrika 29: 1-27.

Martinelli, G.E.; Leal, N.R.; Amaral Júnior, A.T.; Pereira, M.G.; Daher, R.F. 2002. Genetic divergency of okra accessions based on morphological characteristics. Horticultura Brasileira 20: 52-58. (in Portuguese, with abstract in English).

Matheou, A.; Stavropoulos, N.; Samaras, S. 1995a. Studies on table grape germplasm grown in Northern Greece. I. Maturity time, bunch characteristics and yield. Vitis 34: 155-158.

Matheou, A.; Stavropoulos, N.; Samaras, S.1995b. Studies on table grape germplasm grown in Northern Greece. II. Seedlessness, berry and must characteristics. Vitis 34: 217-220.

Micheli, L.; Campostrini, F.; Iacono, F.; Stefanini, M. 1993. Evaluation of genetic divergence among clones by means of phyllometric techniques. Vignevine 20: 64-69.

Nascimento, A.R.P.; Michereff, S.J.; Mariano, R.L.R.; Viana, I.O. 2006. Reaction of grapevine clones to Xanthomonas campestris pv. viticola, based on epidemiological components of bacterial canker. Ciência Rural 36: 1-7. (in Portuguese, with abstract in English).

Nascimento Filho, F.J.; Atroch, A.L.; Souza, N.R.; Garcia, T.B.; Cravo, M.S.; Coutinho, E.F. 2001. Genetic divergence between clones of guarana. Pesquisa Agropecuária Brasileira 36: 501-506. (in Portuguese, with abstract in English).

Oliveira, F.J.O.; Anunciação Filho, C.J.A.; Bastos, G.Q.; Reis, O.V. 2003. Genetic divergence among cultivars of cowpea. Pesquisa Agropecuária Brasileira 38: 605-611. (in Portuguese, with abstract in English).

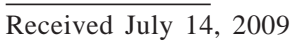

Accepted May 14, 2010 